\title{
Genetic Variability and Association of Characters of Hermaphrodite Papaya Genotypes
}

\author{
Wegayehu Assefa*, Edossa Etissa, Asmare Dagnew, Lemma Ayele, Girma Kebede, \\ Mikiyas Damtew, Merkebu Ayalew
}

Department of Horticulture, Ethiopian Institute of Agricultural Research, Adama, Ethiopia

Email address:

2009wegayehu@gmail.com (W. Assefa)

*Corresponding author

\section{To cite this article:}

Wegayehu Assefa, Edossa Etissa, Asmare Dagnew, Lemma Ayele, Girma Kebede, Mikiyas Damtew, Merkebu Ayalew. Genetic Variability and Association of Characters of Hermaphrodite Papaya Genotypes. Advances in Bioscience and Bioengineering.

Vol. 4, No. 2, 2016, pp. 10-15. doi: 10.11648/j.abb.20160402.11

Received: June 2, 2016; Accepted: June 12, 2016; Published: July 21, 2016

\begin{abstract}
An experiment was conducted to evaluate genetic variability and association of characters of hermaphrodite papaya genotypes for further breeding improvement. Sixteen hermaphrodite papaya genotypes were evaluated at Melkassa Agricultural Research Centre in a randomized complete block design experiment with two replicates from 2011 to 2013. Based on the analysis, the genotypes showed variation in their performances. High heritability coupled with high genetic advance recorded for fruit weight $(94,44.75)$ followed by inter-node length $(86,37.3)$, fruit length $(94,29.25)$, and total number of fruit per plant $(75,30.94)$. Yield per plant exhibited highly significant positive correlation with inter-node length $(0.7,0.58)$, fruit length $(0.49,0.46)$ and fruit diameter $(0.41,0.44)$ both genotypic and phenotypic levels respectively. Based on path coefficient analysis, number of fruits per plant had the highest direct effect (1.05) on fruit yield per plant followed by fruit length $(0.56)$, fruit diameter (0.49) and fruit weight (0.45). The overall results of this study indicated number of fruits, fruit length, fruit diameter, fruit weight and inter-node length exhibited high variation, heritability and genetic advance, and positive direct path coefficient effect on fruit yield per plant. Hence, these traits can be used as principal selection criteria for papaya fruit yield improvement.
\end{abstract}

Keywords: Heritability, Genetic Advance, Association, Path Analysis, Genotypes

\section{Introduction}

Papaya is one of the economically important fruit crops in Ethiopia [2]. Over the years, papaya fruit production in Ethiopia has been increased by $381.57 \%$ continuously from 2005 to 2015 [2, 3]. In addition to providing nutrition security, papaya plays important roles in income generation, export market, employment opportunities and stabilizing the environment [24]. The demand of papaya has been increasing with pull factors such as population growth, income and increased attitude of households in consuming papaya and the wide opportunity for export in neighbouring countries $[2,7]$.

Despite all these facts, lack of improved papaya varieties in the country growers are forced to use mixed, unknown open pollinated genotypes and segregating generation of hybrids in successive plantings; which raises a series of problems in growth, yield and yield component performances. Tropical fruits breeding program at Melkassa Agricultural Research Centre has made collection and continuous controlled pollination of papaya materials to produce sufficient amount of variability, thereby desired lines have been selected for identification of better genotypes with desirable traits and their subsequent use in breeding program. Efforts to improve papaya have been constrained mainly by lack of adequate information on the genetic control of yield and yield related traits of materials.

Variation is the basis for plant breeding and it is the occurrence of differences between individuals due to variation in their genetic composition and/or the environment in which they are grown. To carry out effective selection, information on available genetic variation among papaya 
genotypes, the nature of traits on which selection would be effective and the influence of environmental factors on each trait need to be known $[4,12]$. The observed variability is a combined estimate of genetic and environmental causes of which only the former one is heritable [14]. This may influence selection procedure used by the plant breeder to decide which selection procedure would be the most useful to improve the traits to predict gain from selection and to determine the relative importance of genetic effect [18].

Generally, in a breeding program several traits can be targeted simultaneously, so that the understanding of the genetic associations helps to refine the choice of the most appropriate procedure [4, 14]. Therefore, the aim of the present study was to evaluate genetic variability and association of characters of hermaphrodite papaya genotypes for further breeding improvement.

\section{Materials and Methods}

Sixteen promising hermaphrodite papaya genotypes, namely Wn-139 L,542; MamaoSolmar L\#7; MK-107 L\#401; ML-141 L\#492; CMF-075 L\#60; MK-121 L\# 516; Coorghoneydew L\#5; Bishola-2 L\#138; Hacr-7 L\#176; CMF-008 L\#94; Bishola-1 L\#147; CMF-019 L\#79; KK-103 L\#446; CMF-078 L\#56; KK-103 L\#459 and Alemtena L\#132 were planted at Melkassa Agricultural Research Centre from 2011 to 2013 . The experimental site is located in the Central Rift Valley of Ethiopia at $8^{\circ} 24^{\prime} \mathrm{N}$ latitude and $39^{\circ} 21^{\prime}$ E longitude. It has an elevation of 1550 m.a.s.1..

The genotypes were arranged in Randomized Complete Block Design (RCBD) with two replications. Four seeds were sown per pot. At four to five leaves growth stage the four seedlings in a pot were transplanted to the experimental field. At flowering stage it was thinned to one hermaphrodite plant per stand by removing other plants. The spacings of plantation were 2.5 meters between plants and 2.5 meters between rows. The nursery and field conditions were managed as per Melkassa Agricultural Research Centre recommendations. The following traits were collected: plant height to first flower in $\mathrm{cm}$ (HFF), total height of plant in $\mathrm{cm}$ (THFF), stem girth diameter 30 on above the ground in $\mathrm{cm}$ (GD) and canopywidth in $\mathrm{cm}$ (CW) and inter-node length in $\mathrm{cm}$ (IL) were measured with the tape meter at the age of first flowering. Leaf number (LN) was counted at the age of first flowering. Number of marketable fruits per plant (NMF), total number of fruits per plant (TNF), percentage of unmarketable fruit yield per plant (PUMY), total fruit yield (TY) per plant in kg, marketable fruit yield (MY) per plant in $\mathrm{kg}$, fruit length (FL) in $\mathrm{cm}$, fruit diameter (FD) in $\mathrm{cm}$ and a fruit weight (FW) per plant in $\mathrm{kg}$ were measured. Fruit weight and yield was taken using a field balance.

\section{Data analysis}

The phenotypic and genotypic variance and coefficient of variation were estimated according to the methods suggested by [17]; and genotypic and phenotypic correlations following [22] procedure using Microsoft excels program and Minitab (15) software were calculated from ANOVA table. The coefficients of correlations at genotypic level were tested for their significance using the formula as suggested by [20]. Path coefficient analysis was performed following the procedures of [5] for plant and fruit characters contributing to fruit yield per plant, with a view to their direct and indirect contribution and to assess the relative importance of each causal factor affecting fruit yield.

The coefficient of variance, GCV and PCV were categorized as suggested by [14]: $0-10 \%=$ low, $10-20 \%$ $=$ moderate and $20 \%$ and above $=$ high. Heritability percentage was categorized as demonstrated by [19]: 0-30\% $=$ low, $30-60 \%=$ moderate and $60 \%$ and above $=$ high.

\section{Results and Discussion}

\subsection{Mean and Mean Squares, Ranges and Coefficients of Variation}

Table 1. Mean values, coefficients of variation, ranges and mean squares of agronomic characters of hermaphrodite papaya genotypes at Melkassa.

\begin{tabular}{|c|c|c|c|c|c|c|c|}
\hline \multirow{2}{*}{ Character } & \multirow{2}{*}{ Treatment Mean } & \multirow{2}{*}{ CV (\%) } & \multicolumn{2}{|l|}{ Range } & \multicolumn{3}{|c|}{ Mean square values } \\
\hline & & & Min & Max & Replication & Treatment & Error \\
\hline $\mathrm{HFF}$ & 89.71 & 9.19 & 54.17 & 114.50 & 19.531 & $591.7 * * *$ & 68.0 \\
\hline THFF & 136.28 & 7.53 & 85.92 & 181.75 & 40.88 & $989.56 * * *$ & 105.34 \\
\hline GD & 20.80 & 8.31 & 15.5 & 27.75 & 0.183 & $26.06 * * *$ & 2.98 \\
\hline $\mathrm{CS}$ & 132.15 & 8.71 & 107.50 & 161.25 & 2.26 & $604.7 * *$ & 132.6 \\
\hline $\mathrm{LN}$ & 18.28 & 7.13 & 15.17 & 22.00 & 0.219 & $8.15^{* *}$ & 1.70 \\
\hline IL & 3.90 & 16.36 & 1.99 & 5.42 & 0.131 & $2.92 * * *$ & 0.40 \\
\hline NMY & 88.47 & 21.47 & 45.38 & 149.06 & 586.36 & $1602.87 * *$ & 360.30 \\
\hline PUMY & 22.23 & 21.99 & 6.65 & 35.87 & 3.60 & $69.48 *$ & 24.11 \\
\hline TNF & 106.40 & 20.89 & 49.50 & 173.50 & 717.83 & $1965.52 * *$ & 493.92 \\
\hline TY & 91.42 & 22.83 & 56.14 & 134.49 & 1360.9 & $1445.12 *$ & 435.68 \\
\hline FL & 21.09 & 7.63 & 14.07 & 28.66 & 4.38 & $43.93 * * *$ & 2.59 \\
\hline FD & 9.47 & 3.8 & 8.34 & 10.41 & 0.569 & $0.937 * * *$ & 0.129 \\
\hline AFW & 0.93 & 11.35 & 0.52 & 1.46 & 0.037 & $0.192 * * *$ & 0.011 \\
\hline
\end{tabular}

$\mathrm{HFF}=\mathrm{Mean}$ height up to first flower $(\mathrm{cm}) ; \mathrm{THFF}=$ Mean total height to first flower $(\mathrm{cm}) ; \mathrm{GD}=$ Mean girth diameter $30 \mathrm{~cm}$ above the ground $(\mathrm{cm}) ; \mathrm{CW}=\mathrm{Mean}$ canopy width $(\mathrm{cm})$; $\mathrm{LN}=$ Mean leaf number per tree; $\mathrm{IL}=$ Mean internode length $(\mathrm{cm})$; MY= Mean marketable yield per plant $(\mathrm{kg})$; $\mathrm{NMF}=\mathrm{Mean}$ number ofmarketable fruit/plant; TY= mean total fruit yield per plant, $\mathrm{PUMY}=$ percent of unmarketable yield per plant, $\mathrm{MY}=\mathrm{marketable}$ fruit yield per plant, TNF $=$ Mean total number of fruit/plant; $\mathrm{FL}=$ Mean fruit length $(\mathrm{cm}) ; \mathrm{FD}=$ Mean fruit diameter $(\mathrm{cm})$ and Mean fruit weight $(\mathrm{kg}){ }^{\mathrm{n}}, *$, $* *, * * *=$ non-significant, Significant at 5, 1, 0.1\% probability level, respectively 
Analysis of variance for fourteen characters of hermaphrodite papaya genotypes are presented in table 1 . All the genotypes showed significant differences or variations in their mean performances with respect to the characters studied. This indicates that there was the presence of variability for the characters in the genotypes for further selection and breeding studies.

\subsection{Genetic Variability}

Total number of fruits per plant (TNF) exhibited the highest genetic variance $(\mathrm{GV})$ and phenotypic variance $(\mathrm{PV})$ that were 735.80 and 982.76 , respectively, followed by the total yield per plant (TY) that had GV of 504.72 and PV of 722.56. The lowest GV and PV were recorded for the average fruit weight as 0.09 and 0.1 , respectively, followed by fruit diameter with 0.4 and 0.47 , respectively. These findings are in harmony to $[12,16]$.

The estimated phenotypic coefficient of variability (PCV) was greater than the genotypic coefficient of variation (GCV) in magnitude for all the traits studied. Environmental coefficient of variation (ECV) for most of the traits was less than $10 \%$. High estimates of GCV and PCV were observed for unmarketable fruit yield per plant, 50.29 and 62.24, respectively; while the lowest GCV and PCV were computed for fruit diameter, 6.71 and 7.23, respectively (Table, 2). According to the categories of GCV and PCV proposed by [14], both GCV and PCV values were ranged from moderate to high for all traits studied except for number of leaf per plant and fruit diameter, with less than $10 \%$. The differences between PCV and GCV were generally very low. This indicates low sensitivity of the traits to environmental adjustments, and expression of these traits is dependent more on genetic factors rather than on environmental factors. The high values of PCV and GCV indicated the existence of substantial variability, ensuring better scope for their improvement through selection of the characters. These results are in agreement with the findings of $[15,16]$.

The effectiveness of selection for any character depends not only on the extent of genetic variability but also on the extent of transferring from one generation to the other generation. The highest estimate of broad sense heritability $\left(\mathrm{H}^{2}\right)$ was observed for fruit weight $(94 \%)$ and fruit length (94\%) followed by HFF (89\%), GD (89\%) and THFF $(86.0 \%)$. The minimum heritability was recorded for unmarketable fruit yield per plant $(65 \%)$, followed by total fruit yield per plant (70\%). According to [19] heritability of characters above $60 \%$ is high. Nevertheless, heritability alone does not give an idea about the expected gain in the next generation but it has to be considered in conjunction with the genetic advance.

The genetic advance as percentage for the fourteen traits ranged from 8.72 to 44.75 (Table 2). The highest genetic advance was recorded by fruit weight (44.75) followed by inter-node length (37.3), marketable fruit yield (32.19), total number of fruit (30.94), fruit length (29.25), total fruit yield (28.82) and number of marketable fruit per plant (25.96). High heritability coupled with high genetic advance was observed in fruit weight followed by inter-node and fruit length, and total number of fruit per plant. These traits are relatively more reliable during selection process of the genotype. $[12,16]$ indicated that these traits are predominantly governed by additive gene action, and directional phenotypic selection of these traits could be more effective for desired genetic improvement. The genetic advance and heritability values were relatively moderate for fruit yields per plant (total, unmarketable and marketable). As suggested by [6] selection for these traits may be considerably difficult due to the masking effect of environment on genotypic characters.

Table 2. Variability, heritability and expected genetic advance of some relevant traits of hermaphrodite papaya lines at Melkassa.

\begin{tabular}{lllllllll}
\hline Traits & GV & GCV\% & PV & PCV\% & EV & ECV\% & $\left(\mathbf{H}^{2}\right)$ & \%GA \\
\hline HFF & 261.85 & 18.04 & 295.85 & 19.17 & 34.00 & 6.50 & 0.89 & 23.89 \\
THFF & 442.11 & 15.43 & 494.78 & 16.32 & 52.67 & 5.33 & 0.89 & 20.34 \\
GD & 11.54 & 16.33 & 13.03 & 17.35 & 1.49 & 5.87 & 0.89 & 21.62 \\
CW & 236.05 & 11.63 & 302.35 & 13.16 & 66.30 & 6.16 & 0.78 & 14.37 \\
LN & 3.23 & 9.82 & 4.08 & 11.04 & 0.85 & 5.04 & 0.79 & 12.22 \\
IL & 1.26 & 28.78 & 1.46 & 30.98 & 0.20 & 11.47 & 0.86 & 37.30 \\
MY & 431.75 & 26.82 & 595.35 & 31.50 & 163.60 & 16.51 & 0.73 & 32.19 \\
NMY & 621.025 & 22.00 & 534.02 & 26.12 & 155.15 & 14.08 & 0.71 & 25.96 \\
TNF & 735.80 & 25.49 & 982.76 & 29.46 & 246.96 & 14.77 & 0.75 & 30.94 \\
TY & 504.72 & 24.57 & 722.56 & 29.40 & 217.84 & 16.14 & 0.70 & 28.82 \\
PUMY & 22.68 & 50.29 & 34.74 & 62.24 & 0.06 & 2.68 & 0.65 & 24.13 \\
FL & 20.67 & 21.56 & 21.97 & 22.22 & 1.30 & 5.40 & 0.94 & 29.25 \\
FD & 0.40 & 6.71 & 0.47 & 7.23 & 0.07 & 2.68 & 0.86 & 8.72 \\
AFW & 0.09 & 32.35 & 0.10 & 33.32 & 0.01 & 7.97 & 0.94 & 44.75 \\
\hline
\end{tabular}

$\mathrm{HFF}=$ Mean heightto first flower $(\mathrm{cm})$; THFF= Mean total height to first flower $(\mathrm{cm})$; $\mathrm{GD}=$ Mean girth diameter $30 \mathrm{~cm}$ above the ground $(\mathrm{cm})$; $\mathrm{CW}=\mathrm{Mean}$ canopy width (cm); $\mathrm{LN}=$ Mean leaf number per tree; $\mathrm{IL}=$ Mean inter node length $(\mathrm{cm}) ; \mathrm{MY}=$ Mean marketable yield per plant $(\mathrm{kg}) ; \mathrm{NMF}=\mathrm{Mean}$ number of marketable fruit/plant; $\mathrm{TY}=$ mean total fruit yield per plant, $\mathrm{PUMY}=$ percent of unmarketable yield per plant, $\mathrm{MY}=$ marketable fruit yield per plant, $\mathrm{TNF}=$ Mean total number of fruit/plant; $\mathrm{FL}=$ Mean fruit length $(\mathrm{cm}) ; \mathrm{FD}=$ Mean fruit diameter $(\mathrm{cm})$ and Mean fruit weight $(\mathrm{kg})$. 


\subsection{Character Association}

The phenotypic and genotypic correlation coefficients for different pair of characters are presented in table 3 . The total fruit yield per plant had significant and positive phenotypic and genetic correlations with inter-node length and fruit length and diameter. This suggests that selection for higher inter-node length and fruit size can result in more productive plants. Similar results were reported by [4, 12]. They reported significant positive correlation between the mean annual fruit yield per plant and inter-node length and fruit size. According to [4], the strong association of inter-node length with total fruit yield per plant may be related with a greater capacity of the plants to take up water and nutrients from the soil, resulting in greater vigor and favorable performance of the yield components.

The significant and positive genetic and phenotypic correlations of total number of fruits with inter-node length, girth diameter and number of marketable fruits were observed, but significant and negative with fruit length and fruit weight (table 3). [4] reported significant and negative correlation between fruit number per plant and fruit size. Fruit weight was showed positive and significant phenotypic and genotypic correlation with marketable yield per plant, fruit length and diameter, whereas it had negative phenotypic and genotypic correlation with number of marketable fruit per plant and number of total fruits per plant. A high positive correlation was observed between fruit length and fruit diameter that indicates the fruits of these generations grew proportionally in diameter and length. Similar correlation pattern were reported by [13] between fruit length and fruit diameter, but negative correlation with number of total fruit yield per plant. This result also partially supports the findings of [4] for the traits such as mean fruit length, mean fruit diameter and average fruit weight that were positively correlated with mean marketable fruit yield. In most instances, the genotypic correlations were slightly higher in magnitude than phenotypic correlations indicating strong association between the characters.

Table 3. Phenotypic correlation ( $r p$ ) (above diagonal) and genotypic correlation coefficients ( $\mathrm{rg}$ ) (below diagonal) of thirteen characters for hermaphrodite papaya genotypes.

\begin{tabular}{|c|c|c|c|c|c|c|c|c|c|c|c|c|c|c|}
\hline & HFF & THFF & GD & CS & LN & IL & NMY & MY & NTF & TY & FL & FD & AFW & PUNY \\
\hline $\mathrm{HFF}$ & 1 & $0.88^{* * *}$ & $0.56^{* * *}$ & $0.56^{* * *}$ & $0.19^{\mathrm{n}}$ & $0.07^{\mathrm{n}}$ & $-0.06^{n}$ & $0.02^{\mathrm{n}}$ & $-0.08^{n}$ & $-0.02^{n}$ & $0.03^{\mathrm{n}}$ & $0.27^{\mathrm{n}}$ & $0.08^{\mathrm{n}}$ & $-0.34^{*}$ \\
\hline THFF & $0.93 * * *$ & 1 & $0.60^{* * *}$ & $0.74^{* * *}$ & $0.26^{\mathrm{n}}$ & $0.18^{\mathrm{n}}$ & $0.15^{\mathrm{n}}$ & $0.16^{\mathrm{n}}$ & $0.11^{\mathrm{n}}$ & $0.10^{\mathrm{n}}$ & $0.01^{\mathrm{n}}$ & $0.20^{\mathrm{n}}$ & $0.03^{\mathrm{n}}$ & $-0.32^{\mathrm{n}}$ \\
\hline GD & $0.75^{* * *}$ & $0.69^{* *}$ & 1 & $0.66^{* * *}$ & $0.31^{\mathrm{n}}$ & $0.32^{\mathrm{n}}$ & $0.39^{*}$ & $0.19^{\mathrm{n}}$ & $0.31^{\mathrm{n}}$ & $0.10^{\mathrm{n}}$ & $-0.27^{\mathrm{n}}$ & $-0.04^{\mathrm{n}}$ & $-0.27^{\mathrm{n}}$ & $-0.41^{*}$ \\
\hline $\mathrm{CW}$ & $0.87 * * *$ & $0.39^{*}$ & $0.70^{* *}$ & 1 & $0.37^{*}$ & $0.35^{*}$ & $0.28^{\mathrm{n}}$ & $0.28^{\mathrm{n}}$ & $0.22^{\mathrm{n}}$ & $0.20^{\mathrm{n}}$ & $-0.10^{\mathrm{n}}$ & $0.22^{\mathrm{n}}$ & $-0.04^{\mathrm{n}}$ & $-0.66^{* * *}$ \\
\hline LN & $0.34 *$ & $0.33^{*}$ & $0.24^{\mathrm{n}}$ & $0.33^{*}$ & 1 & $-0.33^{*}$ & $-0.26^{\mathrm{n}}$ & $-0.21^{\mathrm{n}}$ & $-0.32^{\mathrm{n}}$ & $-0.21^{\mathrm{n}}$ & $0.02^{\mathrm{n}}$ & $0.26^{\mathrm{n}}$ & $0.13^{\mathrm{n}}$ & $-0.31^{\mathrm{n}}$ \\
\hline IL & $0.21^{\mathrm{n}}$ & $0.26^{\mathrm{n}}$ & $0.32 *$ & $0.42^{*}$ & $-0.44 * *$ & 1 & $0.49 * *$ & $0.58 * *$ & $0.54 * *$ & $0.58 * * *$ & $0.02^{\mathrm{n}}$ & $0.03^{\mathrm{n}}$ & $-0.05^{\mathrm{n}}$ & $0.30^{\mathrm{n}}$ \\
\hline NMY & $0.17^{\mathrm{n}}$ & $0.0^{\mathrm{n}}$ & $0.48^{*}$ & $0.32 *$ & $-0.32 *$ & $0.56^{* *}$ & 1 & $0.53 * *$ & $0.97 * * *$ & $0.44 * *$ & $-0.43^{*}$ & $-0.29^{\mathrm{n}}$ & $-0.47 * *$ & $-0.24^{\mathrm{n}}$ \\
\hline MY & $-0.01^{\mathrm{n}}$ & $0.05^{\mathrm{n}}$ & $0.21^{\mathrm{n}}$ & $0.27^{\mathrm{n}}$ & -0.21 & $0.67 * *$ & $0.28^{n}$ & 1 & $0.49 * *$ & $0.97 * * *$ & $0.42 *$ & $0.39 *$ & $0.45^{* *}$ & $-0.20^{\mathrm{n}}$ \\
\hline NTF & $-0.22^{\mathrm{n}}$ & $-0.05^{\mathrm{n}}$ & $0.38^{*}$ & $0.2^{\mathrm{n}}$ & $-0.47 * *$ & $0.66^{* *}$ & $0.97^{* * *}$ & 0.23 & 1 & $0.47 * *$ & $-0.42 *$ & $-0.27^{\mathrm{n}}$ & $-0.48 * *$ & $-.08^{\mathrm{n}}$ \\
\hline TY & $-0.07^{\mathrm{n}}$ & $-0.01^{\mathrm{n}}$ & $0.1^{\mathrm{n}}$ & $0.1^{\mathrm{n}}$ & $-0.28^{\mathrm{n}}$ & $0.72 * * *$ & $0.17^{\mathrm{n}}$ & $0.98 * * *$ & 0.14 & 1 & $0.46 * *$ & $0.44 *$ & $0.10^{\mathrm{n}}$ & $-0.01^{\mathrm{n}}$ \\
\hline FL & $0.05^{\mathrm{n}}$ & $-0.02^{\mathrm{n}}$ & $-0.38 *$ & $-0.19^{\mathrm{n}}$ & -0.06 & $0^{\mathrm{n}}$ & $-0.63 * *$ & $0.45^{*}$ & $-0.66^{* *}$ & $0.49^{*}$ & 1 & $0.43^{*}$ & $0.91 * * *$ & $-0.14^{\mathrm{n}}$ \\
\hline FD & $0.34 *$ & $0.17^{\mathrm{n}}$ & $-0.07^{\mathrm{n}}$ & $0.17^{\mathrm{n}}$ & $0.40^{*}$ & $-0.02^{n}$ & $-0.61 * *$ & $0.35 * * *$ & $-0.64 * *$ & $0.41 *$ & & 1 & $0.71 * * *$ & $0.05^{\mathrm{n}}$ \\
\hline AFW & $0.11^{\mathrm{n}}$ & $0.03^{\mathrm{n}}$ & $-0.16^{\mathrm{n}}$ & $-0.11^{\mathrm{n}}$ & $0.20^{\mathrm{n}}$ & $-0.14^{\mathrm{n}}$ & $-0.74 * * *$ & $0.42 * * *$ & $-0.79 * * *$ & $0.48 *$ & $0.95^{* * *}$ & $0.77^{* * *}$ & 1 & $-0.04^{\mathrm{n}}$ \\
\hline PUNY & $-0.33 *$ & $-0.32 *$ & $-0.40 *$ & $-0.67 * *$ & $-0.31^{n}$ & $0.3^{\mathrm{n}}$ & $-0.24^{\mathrm{n}}$ & $0.20^{\mathrm{n}}$ & $-0.08^{n}$ & $-0.01^{n}$ & $-0.14^{\mathrm{n}}$ & $0.05 n$ & $0.04^{\mathrm{n}}$ & 1 \\
\hline
\end{tabular}

$\mathrm{n}, *, * *, * * *=$ non-significant, significant at $5,1,0.1 \%$ probability level, respectively.

$\mathrm{HFF}=$ Mean height to first flower $(\mathrm{cm})$; THFF= Mean total height to first flower $(\mathrm{cm})$; GD= Mean girth diameter $30 \mathrm{~cm}$ above the ground $(\mathrm{cm}) ; \mathrm{CW}=\mathrm{Mean}$ canopy width $(\mathrm{cm}) ; \mathrm{LN}=$ Mean leaf number per tree; $\mathrm{IL}=$ Mean inter node length $(\mathrm{cm})$; $\mathrm{MY}=\mathrm{Mean}$ marketable yield per plant $(\mathrm{kg})$; $\mathrm{NMF}=\mathrm{Mean}$ number of marketable fruit/plant; TY= mean total fruit yield per plant, $\mathrm{PUMY}=$ percent of unmarketable yield per plant, $\mathrm{MY}=$ marketable fruit yield per plant, TNF = Mean total number of fruit/plant; $\mathrm{FL}=$ Mean fruit length $(\mathrm{cm}) ; \mathrm{FD}=$ Mean fruit diameter $(\mathrm{cm})$ and Mean fruit weight $(\mathrm{kg})$.

\subsection{Path Coefficient Analysis}

Due to mutual cancellation of component traits, the estimation of correlation alone may be often misleading so it is necessary to study the path co-efficient analysis which takes into account the casual relationship in addition to the degree of relationship [11].

The direct effect of the plant height at first flower on fruit yield was low but positive. It had also indirect low but positive effect on girth diameter, leaf number, inter-node length, number of marketable fruits, fruit length, and average fruit weight, but moderate on fruit diameter. The direct effect of the total height on yield was negative and low. However, the indirect effect on height at first flower, girth diameter, leaf number, inter-node length, marketable yield, fruit diameter and average fruit weight was low and positive. The result indicated that considering plant height to first flower and total height of plant for fruit yield improvement as principal elements was not rewarding due to its low direct and indirect effect on major yield components. This result to partially support the findings of [21]; they reported that total plant height high negative direct effects on fruit yield per plant.

The direct effect of girth diameter on fruit yield was very low and negative. The indirect effects on height to first flower, leaf number, inter node length, number of marketable fruits and marketable yield were positive but low, though a high value was recorded through number of total fruit. Canopy width had moderate negative direct effect on fruit yield with positive indirect effects for height to first flower, girth diameter, leaf number, inter node length, number of marketable yield, marketable yield and fruit diameter, but 
moderate indirect effect on total number of fruits. The direct selections for the traits were not found important for fruit yield improvement as its positive effect was indirect through other several yield components.

The direct effect of fruit length on fruit yield was high and positive and the indirect effects on total number of fruit and number of marketable fruit was high and negative, but it had high and positive indirect effect on average fruit weigh. The direct influence of fruit diameter was high and positive and a high positive indirect influence on fruit length and average fruit weight, but negative and high indirect effect on total number of fruit. Fruit weight had also high direct positive effect on fruit yield and also produced a high indirect positive effect on fruit length and fruit diameter. The direct selection for fruit size and fruit weight were found important for fruit yield improvement of hermaphrodite papaya as its direct high positive effect on fruit yield and positive indirect effect on other traits. Similarly [16] reported that high positive direct effect of fruit length and average fruit weight on fruit yield per plant.

Number of fruits had the highest direct positive effect on fruit yield and moderate positive indirect effect on number of marketable fruits. Considering the number of fruits per plant in the selection program was rewarding for papaya fruit yield, but due to its high and negative indirect effect on fruit length, diameter and average fruit weight which had high and direct effect on fruit yield it could not be taken as a separate parameter for fruit yield improvement. These findings are in accordance with $[4,12,16]$.

Table 4. The direct and indirect effects of path coefficient analysis of thirteen characters for hermaphrodite papaya genotypes.

\begin{tabular}{|c|c|c|c|c|c|c|c|c|c|c|c|c|c|c|}
\hline & HFF & THFF & GD & $\mathrm{CS}$ & $\mathbf{L N}$ & IL & NMY & MY & NTF & FL & FD & AFW & PUNY & rg \\
\hline HFF & 0.021 & -0.048 & 0.014 & -0.126 & 0.043 & 0.004 & 0.031 & -0.001 & -0.232 & 0.028 & 0.167 & 0.050 & -0.021 & -0.07 \\
\hline THFF & 0.020 & -0.051 & 0.013 & -0.056 & 0.041 & 0.005 & 0.000 & 0.006 & -0.053 & -0.011 & 0.084 & 0.014 & -0.021 & -0.01 \\
\hline GD & 0.016 & -0.035 & 0.018 & -0.101 & 0.030 & 0.007 & 0.086 & 0.023 & 0.401 & -0.213 & -0.034 & -0.072 & -0.026 & 0.1 \\
\hline $\mathrm{CS}$ & 0.019 & -0.020 & 0.013 & -0.144 & 0.041 & 0.009 & 0.058 & 0.030 & 0.211 & -0.106 & 0.084 & -0.050 & -0.044 & 0.1 \\
\hline LN & 0.007 & -0.017 & 0.004 & -0.048 & 0.125 & -0.009 & -0.058 & -0.023 & -0.496 & -0.034 & 0.197 & 0.090 & -0.020 & -0.28 \\
\hline IL & 0.005 & -0.013 & 0.006 & -0.061 & -0.055 & 0.021 & 0.101 & 0.074 & 0.696 & 0.000 & -0.010 & -0.063 & 0.020 & 0.72 \\
\hline NMY & 0.004 & 0.000 & 0.009 & -0.046 & -0.040 & 0.012 & 0.180 & 0.031 & 1.023 & -0.353 & -0.300 & -0.333 & -0.016 & 0.17 \\
\hline MY & 0.000 & -0.003 & 0.004 & -0.039 & -0.026 & 0.014 & 0.050 & 0.111 & 0.243 & 0.252 & 0.172 & 0.189 & 0.013 & 0.98 \\
\hline TNF & -0.005 & 0.003 & 0.007 & -0.029 & -0.059 & 0.014 & 0.175 & 0.025 & 1.055 & -0.370 & -0.315 & -0.356 & -0.005 & 0.14 \\
\hline FL & 0.001 & 0.001 & -0.007 & 0.027 & -0.008 & 0.000 & -0.113 & 0.050 & -0.696 & 0.560 & 0.256 & 0.428 & -0.009 & 0.49 \\
\hline FD & 0.007 & -0.009 & -0.001 & -0.025 & 0.050 & 0.000 & -0.110 & 0.039 & -0.675 & 0.291 & 0.492 & 0.347 & 0.003 & 0.41 \\
\hline AFW & 0.002 & -0.002 & -0.003 & 0.016 & 0.025 & -0.003 & -0.133 & 0.046 & -0.833 & 0.532 & 0.379 & 0.450 & 0.003 & 0.48 \\
\hline PUNY & -0.007 & 0.016 & -0.007 & 0.097 & -0.039 & 0.006 & -0.043 & 0.022 & -0.084 & -0.078 & 0.025 & 0.018 & 0.065 & -0.01 \\
\hline
\end{tabular}

$\mathrm{HFF}=$ Mean height up to first flower $(\mathrm{cm}) ; \mathrm{THFF}=$ Mean total height to first flower $(\mathrm{cm}) ; \mathrm{GD}=$ Mean girth diameter $30 \mathrm{~cm}$ above the ground $(\mathrm{cm})$; $\mathrm{CW}=\mathrm{Mean}$ canopy width $(\mathrm{cm})$; LN= Mean leaf number per tree; $\mathrm{IL}=$ Mean inter node length $(\mathrm{cm})$; $\mathrm{MY}=\mathrm{Mean}$ marketable yield per plant $(\mathrm{kg})$; $\mathrm{NMF}=\mathrm{Mean}$ number of marketable fruit/plant; TY= mean total fruit yield per plant, $\mathrm{PUMY}=$ percent of unmarketable yield per plant, $\mathrm{MY}=$ marketable fruit yield per plant, $\mathrm{TNF}=$ Mean total number of fruit/plant; $\mathrm{FL}=$ Mean fruit length $(\mathrm{cm}) ; \mathrm{FD}=$ Mean fruit diameter $(\mathrm{cm})$ and Mean fruit weight $(\mathrm{kg})$, $\mathrm{rg}=\mathrm{genotypic}$ correlation for papaya fruit yield.

\section{Conclusion}

The present study showed variability among the studied hermaphrodite papaya genotypes. The results demonstrated that all GCV and PCV values were moderate to high for all traits studied except for number of leaf per plant and fruit diameter, which registered less than $10 \%$. However, the differences between phenotypic and genotypic coefficient of variations were very low, which indicated that there was a predominance of genetic factors controlling variability in these traits. High heritability coupled with high genetic advance was observed in fruit weight followed by inter-node and fruit length, and total number of fruits per plant. This clearly indicated the additive gene action which governs these traits, and improvement of any of these traits could be made through standard selection methods. The genotypic and phenotypic correlation coefficients were close in most comparisons. The genotypic correlation coefficient values were higher in magnitude which showed the inherent association of these characters. Overall significant and positive phenotypic and genetic association existed between fruit yield and inter-node length, fruit length, fruit diameter and number of marketable fruits per plant. The path coefficient analysis also revealed that number of fruits per plant had the highest direct positive effect on fruit yield followed by fruit length, fruit diameter, average fruit weight, leaf number and inter-node length. In general, results of this study indicated number of fruits, fruit length, fruit diameter, fruit weight and inter-node length exhibited high phenotypic and genotypic coefficients of variation, high heritability and genetic advance, and direct path coefficient effect on fruit yield per plant. Therefore, these traits can be used as principal selection criteria for hermaphrodite papaya genotypes for yield improvement.

\section{References}

[1] Allard, R. W, 1960. Principles of Plant Breeding. John Willy and Sons, Inc., New York, USA.

[2] CSA (Central Static Agency). 2015. Agriculture Sample Survey Report on area and production for major Crops (Private holdings, main season). Statical Volume. 1. Central Static Authority of Ethiopia, Addiss Abeba, Ethiopia. pp: 11-19 
[3] CSA (Central Static Agency). 2005. Agriculture Sample Survey Report on area and production for major Crops (Private holdings, main season). Statical Volume. 1. Central Static Authority of Ethiopia, Addiss Abeba, Ethiopia. 10-20

[4] da Silva, F. F, M. G. Pereira, H. C. C. Ramos, P. C. D. Junior, T. N. S. Pereira, A. P. C. Gabriel, A. P. Viana and G. A. Ferreguetti, 2007. Selection and estimation of the genetic gain in segregating generations of papaya. Crop Breed. Appl. Biotechnol. 8 (1): pp: 1-8.

[5] Dewey, D., K. H. Lu, 1959. A correlation and path coefficient analysis of components of crested wheat grass seed production. Agronomy Journal 51: pp: 515-518

[6] Dwiwedi, A. K., P. K. Ghanta, and S. K. Mitra, 1999. Genetic variability, heritability and genetic advances relating to some fruit characters in Papaya. South Indian Hort. 43: pp: 73-76.

[7] Ethiopian Investment Commission. 2014. Business opportunity for horticulture: http://ethioinvest.net/investmentopportunities/stratei-sectors/horticulture. pp: (Accessed on May 22, 2016).

[8] Evans, E. A. and F. H. Ballen. 2012. An overview of global papaya production, trade and consumption," in Topics: Food and Resource Economics, Extension service Institute of Food and Agricultural (IFAS), FE913, pp: 1-7, University of Florida, Gainesville, Fla, USA

[9] FAO. 2013. Rom United Nations Food and Agriculture Organization. http://faostat3.fao.org/download/Q/QC/E. (Accessed on May 10, 2016).

[10] Fuentes, G. and J. M. Santamaría, 2014. "Chapter 1: papaya (Carica papaya L.): origin, domestication, and production. Genetics and genomics of papaya," in Plant Genetics and Genomics: Crops and Models, Springer. Vol. 10, pp: 3-15.

[11] Hohenboken, W. D. 1985. Phenotypic, genetic and environmental correlations. In: general and Quantitative Genetics. Chapman A. B. (ed). Elsevier Science Publishers, B. V. Amsterdam. pp: 121-134.

[12] Jambhale, V. M., N. S. Kute, and S. V. Pawar. 2014. Studies on genetic variability parameters, character association and path analysis among yield and yield contributing traits in papaya carica papaya (1.) the bioscan. 9 (4): pp: 1711-1715

[13] Jana, B. R., M. Rai, B. Das, and V. Nath. 2005. Genetic variability and association of component characters for fruit yield in papaya (carica papaya L.). The orissa journal of horticulture Vol 33 (1). pp: 90-95

[14] Johnson, H. W., H. F. Robinson, and R. E. Comstock. 1955. Estimates of genetic and environmental variability in soybeans. Agronomy Journal 47: pp: 314-318.

[15] Karunakaran, G., H. Ravishankar, and M. R. Dinesh. 2010. Genetical studies in papaya (Carica papaya L). Acta Horticulturae 851: pp: 103-108.

[16] Kumar, M., K. M. Prasad, S. Prakash, and S. Kumar. 2015. Evaluation of Genetic Variability, Genetic advance, Heritability and Character association for Yield and its Contributing traits in Papaya (Carica papaya L.). VEGETOS. Vol. 28 (2): pp: 99-102

[17] Miller, P. A., J. C. Williams, H. F. Robinson and R. F. Comstock. 1958. Estimation of genotypic and environmental variances and covariances in upland cotton and their implications in selection. Agronomy Journal 50: pp: 126-131.

[18] Oliveira, E. J., G. A. F. Filho, J. P. X. de Freitas, J. L. L. Dantasand, M. D. V. de Resende, 2012. Plant selection in $F_{2}$ segregating populations of papaya from commercial hybrids. Crop Breeding and Applied Biotechnology 12: pp: 191-198

[19] Robinson, H. F., R. E. Comstock and V. H. Harvey. 1949. Agronomy Journal. 41

[20] Robertson, G. E. 1959. The sampling variance of the genetic correlation coefficient. Biometrics 15: pp: 469-485

[21] Shimeles A., A. Bekele, W. Dagne and T. Adeferis. 2016. Genetic variability and association of characters in Ethiopian hot pepper (capsicum annum 1.) landraces. Journal of Agricultural Sciences Vol. 61, No. 1. pp: 19-36

[22] Singh, R. K., B. D. Chaudhary. 1985. Biometrical Methods in Quantitative Genetics Analysis, $2^{\text {nd }}$ ed. Kalyani Publishers, New Delhi, India.

[23] Silva, F. F., M. G. Pereira, W. F. Campos, P. C. Junior Damasceno, T. N. S. Pereira, F. G. A Souza, H. C. C. Ramos, A. P. Vianaand, G. A. Ferreguetti. 2007. DNA marker-assisted sex conversion in elite papaya genotype (Carica papaya L.). Crop Breeding and Applied Biotechnology 7: pp: 52-58.

[24] Tsegaye, D., A. Ahmed, Z. Dilnesaw. 2009. Availability and consumption of fruits and vegetables in nine regions of Ethiopia with special emphasis to vitamin a deficiency. Ethiop. J. Health Dev.; 23 (3): Pp 216-222 